\title{
MicroRNA regulators of cholinergic signaling link neuromuscular, cardiac and metabolic systems
}

\author{
CLAUDIA PIENICA \\ HERMONA SOREQ \\ Department of Biological Chemistry \\ and The Edmond \& Lily Safra Center \\ for Brain Sciences \\ The Hebrew University of Jerusalem \\ Jerusalem 9190401, Israel

\section{Correspondence:} \\ Hermona Soreq \\ hermona.soreq@mail.huji.ac.il \\ Keywords: Amyotrophic lateral sclerosis, \\ Cholinergic, MicroRNAs, miR-206, miR-132, \\ miR-1, Organophosphate poisoning
}

Received August 25, 2016. Revised October 12, 2016. Accepted October 19, 2016.

\begin{abstract}
The neurotransmitter acetylcholine (ACh) notably regulates many brain and bodily functions, including metabolic as well as heart and muscle activities. Concordantly, acquired changes in ACh signaling lead to significant and widespread systemic effects. Those can be observed both when ACh signaling fails, as in the motor neuron disease amyotrophic lateral sclerosis (ALS) and when it over-reacts, as in the hyper-cholinergic excitation following organophosphate poisoning. To explore the corresponding molecular mechanisms, we focused on regulation of ACh signaling by microRNAs (miRs). Current research implicates miRs as post-transcriptional modulators of gene expression, playing pivotal, rapid and interactive roles across various systems. To interrogate the systemic role of ACh-regulating miRs (CholinomiRs), we sought evidence for CholinomiRs with dual or triple roles in neuromuscular junctions (NMJ), heart development and functioning, andl or metabolic systems. Here, we report key links between CholinomiRs with known cardiac and metabolic roles, including the nicotinic acetylcholine receptor-targeted miR-1 and the acetylcholinesterase-targeted miR-132, and NMJ-related metabolic regulating miRs such as the histone deacetylase 4-targeted miR-206. Taken together, this information indicates a bridging role for CholinomiRs that may be relevant both for NMJ degeneration and the metabolic changes observed in ALS patients, and for the cardiac irregularities and NMJ degeneration reported following organophosphate poisoning. Uncovering the potentially causal involvement of CholinomiRs in balancing neuromuscular, cardiac and metabolic functions might improve our understanding of the inter-tissue communication and the processes of reaching homeostatic states which are essential for balancing between seemingly separate body systems, allowing a more encompassing look on disorders involving impaired cholinergic signaling.
\end{abstract}

\section{CHOLINERGIC SIGNALING IMPAIRMENTS SPAN MULTIPLE TISSUES}

The neurotransmitter acetylcholine (ACh) has been the very first

1 chemical neurotransmitter to be identified $(1,2)$. ACh notably regulates numerous brain and bodily functions, including metabolic $(3,4,5)$, cardiac $(6)$ and muscle development and activities $(7,8,9)$. Compatible with the crucial regulatory role of this neurotransmitter in many multi-tissue functions, acquired changes in ACh signaling lead to significant and widespread systemic effects $(10,11,12)$. Those can be observed both when ACh signaling fails, as in the motor neuron disease amyotrophic lateral sclerosis (ALS) $(13,14,15)$ and when it over-reacts, as in the hyper-cholinergic excitation following organophosphate poisoning $(16,17)$. Based on this compelling evidence, we predicted the 
existence of a rapid and efficient surveillance mechanism(s) which can send messages between different tissues when ACh signaling is imbalanced, and adjust its levels to the new needs for reaching homeostasis. In the following, we argue that miRs targeted to cholinergic genes and their upstream regulators may fit this description.

\section{MIRS AS A REGULATORY SYSTEM}

MiRs are small non-coding RNA molecules that are involved in post-transcriptional regulation of mRNA translation and stability. By partially binding to sequences primarily located on the 3'-untranslated region (3'UTR) of mRNA molecules, miRs can lead to simultaneous de-adenylation, translational repression and cleavage of those mRNA molecules that carry such complementary motifs (18). Functional studies indicate miRs involvement in a broad range of cellular and developmental processes such as the cell cycle (19), learning and memory formation and maintenance (20), energy metabolism (21) and many others. The mRNA targets of miRs include a sequence of at least 7 nucleotides which is complementary to the 'seed' region of the miR, and recent evidence suggests that other characteristics add to the specificity of that pairing (22). While some miRs are tissue-specific, a significant amount of them is present in different tissues. One miR can thus simultaneously influence multiple pathways, and regulate different, yet specific targets. Furthermore, miRs may be transported between tissues, for example by being packaged in exosomes $(23,24,25)$, adding inter-tissue communication to their surveillance power. Altogether, miRs provide a rapid and economically efficient regulatory step over gene expression as well as inter-tissue coordination of multi-organ functioning, precisely those features that one would predict for ACh controlling entities.

\section{MIRS IN THE NEUROMUSCULAR JUNCTION}

The great majority of miR studies primarily focus on their impact on tumor biology and/or the nervous system. Nevertheless, an increasing amount of research provides evidence for miRs involvement in muscle development and maintenance. We predicted that CholinomiRs, those miRs which regulate ACh-related functions (1) in one or more systems would also be involved in ACh roles in other tissues. A prominent example is that of miR-1, which was initially discovered in nematodes as a regulator of two subunits of the nicotinic $\mathrm{ACh}$ receptor $\mathrm{nAChR}$ (UNC-29 and UNC-63) (26) and has more recently been shown to be important for post-mitotic growth of larval muscle in a fly model (27). In this experiment Drosophila miR-1 (DmiR-1) knock-out mutant lethality was rescued when a DmiR-1 transgene was expressed in the mesoderm and muscle. It was further suggested by the researchers that miR-1 essentially maintained muscle cell identity and survival by inactivating the expression of non-muscle genes. This is corroborated by evidence showing that miR1 operates as a down-regulator of the histone deacetylase HDAC4, which is known to inhibit muscle cell differentiation $(28,29)$. Furthermore, miR-1 was shown, alongside miR-206 which is also targeted to HDAC4, to promote the differentiation of skeletal muscle satellite cells in favor of proliferation, allowing growth and repair of postnatal skeletal muscle $(30,31)$. Via HDAC4-targeting, miR-206 promotes muscle regeneration and re-innervation following injury $(32,33)$. Also, increases in the levels of miR-132, a known regulator of Acetylcholinesterase (AChE), potentiate $\mathrm{ACh}$ signaling in brain and body alike $(34,35)$. MiR-132 has further been proposed as a biomarker for the moto-neuron disease spinal muscular atrophy (SMA), showing significantly higher levels in patients as opposed to controls (36). Thus, several known miRs play significant roles in various events along the life span of motor neurons, NMJs and muscles across multiple organisms, such as development, differentiation, functional maintenance, and regeneration after injury.

\section{MIRS IN HEART DEVELOPMENT AND FUNCTION}

Multiple miRs have been identified in cardiac tissue at all stages of development. Cardiac-specific knockout of Dicer, a gene encoding an RNase III endonuclease that is essential for miR processing, leads to rapid heart failure and postnatal lethality, showing the importance of cardiac miRs (37). For the purpose of this review, we will focus mainly on miR-1 and miR-132 in cardiac functioning. Importantly, miR-1 promotes pluripotent progenitor cells or stem cells to adopt cardiac characteristics during cardiogenesis (38). Furthermore, miR-1 is causally involved in the electrophysiological functioning of the heart, via regulating levels of the GJA1 and KCNJ2 channels that are believed to contribute to the arrhytmogenic potential (39). In mouse models, miR-1 over-expression impairs cardiac contractile function, most likely by targeting cMLCK and $\mathrm{CaM}$, as well as by inducing anteriorventricular block $(40,41)$. CaM is an upstream activator of CaMKII (42). A decrease in CAMKII activity has been reported to initiate changes in myofibril thick filament structure, resulting in decreased interaction of myosin heads with actin thin filaments (43). The cMLCK kinase phosphorylates regulatory light chains in the heart, and a decrease in RLC phosphorylation has been shown to promote myocyte hypertrophy in vivo (44). MiR-1 is also dysregulated in mouse ventricles during development of severe hypertrophic cardiomyopathy and heart failure (45). Thus, accurate miR-1 levels are important for correct cardiac functioning.

MiR-1 is not the only miR involved with cardiac activities. Rather, miR-132, apart from its neural and immune role, is also involved in heart functioning, along 
Table 1. miR-1, miR-132 and miR-206 presence and influence in cardiac, metabolic and muscular system

\begin{tabular}{|llcc|}
\hline Organism & Function affected & Body system & miRNA \\
\hline $\begin{array}{l}\text { Drosophila, Mouse, } \\
\text { Rats }\end{array}$ & $\begin{array}{l}\text { Mediates cell cycle arrest and differentiation of cardiomyocyte during chamber } \\
\text { development (75) } \\
\text { Promotes electrical and contractile heart irregularities (76,39,40,41) }\end{array}$ & Heart \\
$\begin{array}{l}\text { Xenopus laevis, Human } \\
\text { (in vitro), C. elegans }\end{array}$ & $\begin{array}{l}\text { Promotes myogenesis during development (28) } \\
\text { Downregulates muscle sensitivity to and pre-synaptic release of ACh (26) }\end{array}$ & Muscle \\
Human (in vitro) & Downregulation PPP-dependent NADPH production and ribose synthesis (77) & Metabolism \\
Mouse & Upregulation in cardiomyocytes promoting hypertrophy and heart failure (48) & Heart \\
Mouse & Downregulation AChE levels (58) & Muscle \\
Human & Promotes inflammation in visceral adipose tissue (78,79,80,81) & Metabolism \\
Drosophila & Promotes cardiomyocyte hypertrophy (49) & Heart \\
Mouse & Promotes muscle cell re-innervation (32,33) & Muscle \\
Human (in vitro) & Downregulation PPP-dependent NADPH production and ribose synthesis, & Metabolism \\
\hline
\end{tabular}

with its tandem miR-212. Mir-132 is highly expressed in rat hearts and aortic wall following hypertension and cardiac hypertrophy (46). In addition, miR-132 and miR-212 levels are upregulated by hypertrophic stimuli in mice and are both necessary and sufficient to drive the hypertrophic growth of cardiomyocytes (47). Consequently, miR$212 / 132^{\mathrm{KO}}$ mice that lack these two important miRs are protected from pressure-overload-induced heart failure, whereas miR-212/132 overexpression in cardiomyocytes leads to pathological cardiac hypertrophy and severe heart failure and death in mice (47). In Drosophila as well, miR206 is involved in cardiac hypertrophy through its YAP target (48), although little is known concerning this miR's role in the fly's cardiac function. To conclude, miR-1, miR-132 and miR-206 are all important for correct heart development and their dysregulated levels may cause pathological cardiac conditions.

\section{CHOLINOMIRS AT THE NMJ: ALS AND ORGANOPHOSPHATE POISONING AS MODELS}

The NMJ is a specialized synapse, enabling communication between the nervous system and skeletal muscles; and it makes use of the chemical transmitter ACh for relaying electrical impulses. Notably, ACh signaling in the NMJ can be regulated by CholinomiRs at multiple stages (49). In C. elegans, miR-1 regulates the expression of the UNC-29 and UNC-63 nAChR subunits as well as the muscle transcription factor MEF-2, such that its levels regulate presynaptic ACh secretion (26). In mammals, miR-1 provides a surveillance over epigenetic processes in the NMJ by targeting the histone deacetylase HDAC4 $(29,30)$. Intriguingly, HDAC4 also operates as a mediator of long-lasting stress-inducible changes in AChE's promoter choices in the hippocampus (50). This histone modifier also regulates $\mathrm{nAChR}$ expression following skel- etal muscle denervation (51), making miR-1 a global upstream regulator of ACh signaling. HDAC4 is also elevated in the skeletal muscle of patients with the motor-neuron disease ALS (52). Predictably, miR-206, having an identical seed sequence to miR-1, also regulates HDAC4 levels (33). Multiple studies have provided evidence for the important role of miR-206 in muscle regeneration and protection from muscular atrophy (53). In a mouse model for ALS, miR-206 ${ }^{\mathrm{KO}}$ mutants showed faster progression of the disease, most likely due to delayed muscle re-innervation compared to mice with the functioning miR-206 allele (33). At a later stage of ACh signaling, where ACh degradation terminates such signals, miR-132 emerged as direct regulator of AChE levels (34).

Organophosphate poisoning, most commonly caused by exposure to insecticides or nerve agents, interrupts ACh signaling at all of the above systems and more. Such poisoning causes drastic hyper-cholinergic stimuli by instantaneously arresting ACh degradation by AChE, and one outcome of such poisoning involves rapid changes in AChE gene expression (54). In civil terms, agricultural use of organophosphate insecticides is very common, with an estimate of a hundred thousand fatalities annually and many severe symptoms, including cognitive and cardiac ones among survivors $(55,56)$. The organophosphates inactivate AChE by phosphorylating the serine hydroxyl residue on the enzyme (57). This leads to ACh accumulation at the NMJ causing hyper-cholinergic stimulation. Moreover, mice exposed to miR-132 antisense molecules prior to organophosphate poisoning sustain higher $\mathrm{AChE}$ levels and show a higher survival and recovery rate compared to naïve animals (58). Collectively, this evidence suggests causal involvement of CholinomiRs in both normal neuromuscular development as well as pathological states such as ALS and following organophosphate poisoning. 
The main organophosphate-induced damage is done at the NMJ, where AChE inactivation causes ACh accumulation and overstimulation followed by blocking of ACh signaling (59). Cardiac irregularities, along with a wide range of other symptoms, occur frequently following organophosphate poisoning; and arrhythmias can often be the cause of death $(60,61,62)$. Both miR-132 and miR1 overexpression contribute to cardiac irregularities $(39,40,41,46,47)$ and have roles in neuromuscular desensitization $(26,58)$. Therefore, miR-1 and miR-132 may modulate both the cardiac and the neuromuscular symptoms observed following organophosphate poisoning. Such a mechanism might provide a possible explanation for the very rapid and widespread symptoms following exposure to organophosphates, concordant with the rapid and efficient miR biogenesis. That miR-1 regulates retrograde signaling by targeting MEF-2, decreasing presynaptic ACh release is compatible with that prediction. It is tempting to speculate that miR-1 levels rise, which decreases presynaptic ACh release following organophosphate poisoning, in an attempt to compensate for the synaptic over-activation following $\mathrm{AChE}$ inhibition. Given that miR-132 downregulation increases survival and recuperation after exposure compared to naïve animals (58), it might be interesting to see if miR-1 downregulation provides the same results and if such treatment exerts any changes at the cardiac level.

\section{MIR-206 AS A BRIDGE BETWEEN ALS- INDUCED NMJ DEGENERATION AND METABOLIC CHANGES}

Despite technological challenges, miRs are rapidly rising as possible biomarkers and therapeutic targets for numerous pathological states $(56,61)$. In a study aiming to find biomarkers for ALS, researchers compared miR alterations from skeletal muscle and plasma in the ALS mouse model to the levels of the affected miRs in the serum from human ALS patients (64). ALS is notably characterized by cycles of denervation and subsequent reinnervation. Correspondingly, elevated levels of miR-206, involved in muscle re-innervation, emerged as a promising biomarker for ALS. It is thus possible that the initial denervation in NMJ's induces increases in miR-206 levels which promotes re-innervation.

Aside from motor neuron degeneration, ALS is associated with several defects in energy metabolism $(65,66$, 67,68), and a better metabolism correlates with longer survival of ALS patients $(69,70,71)$. Alongside other metabolic features, augmenting glucose intolerance is considered a sign of deteriorating and dysregulated metabolic homeostasis progressing along with the disease $(66,72)$. Interestingly, recent research has identified miR-206's involvement in the downregulation of enzymes involved in metabolism. Thus, miR-206 ${ }^{\mathrm{KO}}$ mutant mice show increased glucose tolerance and potentiated transcription of glucose metabolism-related enzymes (73). This suggests that over-expression of miR-206, as can be observed in ALS patients and the corresponding mouse models, exerts detrimental effects on glucose tolerance. It is tempting to suggest that the attempt for NMJ re-innervation involves increasing miR-206 levels, but damages metabolic function, in turn leading to more NMJ degeneration. According to this prediction, miR-206 might operate both as a slowing and as an accelerating factor for ALS symptoms.

\section{CONCLUDING REMARKS}

The apparent and predicted involvement of miRs in modulating the effects of ALS and the NMJ, as well as cardiac and metabolic symptoms following organophosphate poisoning might provide new ways to detect and treat such pathological states. The involvement of miRs might also explain the differences between people in the severity and progression of the pathologies, as single nucleotide polymorphisms (SNPs) in the miR target genes might lead to differential downregulation of the miR targets. This is corroborated by the elevated AChE levels in carriers of a miR-608 disrupting SNP in the AChE gene (74) as well as by the differences in miR-206 and HDAC4 expression between patients with rapidly decaying and slowly progressing ALS (33). Although there was a significant difference between ALS patients and control subjects in miR-206 expression, no difference was measured in miR-206 levels between patients with rapidly progressing ALS and long surviving ALS patients. The levels of the miR-206-targeted HDAC4, on the other hand, were significantly higher in rapidly progressive ALS, suggesting impaired binding of miR-206 to its target, possibly due to a yet undefined SNP or other, further removed molecular differences. In conclusion, further research concerning CholinomiRs involvement in these pathological states, as well as in normal development is required and could provide us with better targeted therapeutics.

\section{ACKNOWLEDGMENTS}

This work was supported by the European Research Council Advanced Award 321501 and the Israel Science Foundation Grant No. 378/11 (to H.S.).

\section{REFERENCES}

1. SOREQ H 2015 Checks and balances on cholinergic signaling in brain and body function. TRENDS NEUROSCI 38:448-58. https://doi.org/10.1016/j.tins.2015.05.007

2. PICCIOTTO MR, HIGLEY MJ, MINEUR YS 2012 Acetylcholine as a Neuromodulator: Cholinergic Signaling Shapes Nervous System Function and Behavior. Neuron 76:116-129. https://doi.org/10.1016/j.neuron.2012.08.036

3. LIMA JK, LEITE N, TUREK LV, SOUZA RL, DA SILVA TIMOSSI L, OSIECKI AC, OSIECKI R, FURTADO-ALLE 2013 
L1914G variant of BCHE gene associated with enzyme activity, obesity and triglyceride levels. Gene 532:6-24

4. GAUTAM D, HAN SJ, HAMDAN FF, JEON J, LI B, LI JH, CUI Y, MEARS D, LU H, DENG C, HEARD T, WESS J 2006 Critical metabolic roles of $\beta$-cell M3 muscarinic acetylcholine receptors Cell Metab 3:449-61. https://doi.org/10.1016/j.cmet.2006.04.009

5. KOLISNYK B, AL-ONAIZI MA, HIRATA PH, GUZMAN MS, NIKOLOVA S, BARBASH S, SOREQ H, BARTHA R, PRADO MA, PRADO VF 2013 Forebrain Deletion of the Vesicular Acetylcholine Transporter Results in Deficits in Executive Function, Metabolic, and RNA Splicing Abnormalities in the Prefrontal Cortex J Neurosci 33:14908-20

6. ARBEL Y, SHENHAR-TSARFATY S, WAISKOPF N, FINKELSTEIN A, HALKIN A, REVIVO M, BERLINER S, HERZ I, SHAPIRA I, KEREN G, SOREQ H, BANAI S 2014 Decline in serum cholinesterase activities predicts 2-year major adverse cardiac events. Mol Med 20:38-45.

https://doi.org/10.2119/molmed.2013.00139

7. BEHRA M, COUSIN X, BERTRAND C, VONESCH JL, BIELLMANN D, CHATONNET A, STRÄHLE U 2002 Acetylcholinesterase is required for neuronal and muscular development in the zebrafish embryo. Nat Neurosci 5:111-8.

https://doi.org/10.1038/nn788

8. GOLDMAN D, STAPLE J 1989 Spatial and temporal expression of acetylcholine receptor RNAs in innervated and denervated rat soleus muscle. Neuron 3:219-228.

https://doi.org/10.1016/0896-6273(89)90035-4

9. LIN W, DOMINGUEZ B, YANG J, PRAFULLA ARYAL P, BRANDON EP, GAGE FH, LEE KF 2005 Neurotransmitter Acetylcholine Negatively Regulates Neuromuscular Synapse Formation by a Cdk5-Dependent Mechanism. Neuron 46: 569-579. https://doi.org/10.1016/j.neuron.2005.04.002

10. PIMLOTT SL, PIGGOTT M, OWENS J, GREALLYE, COURT JA, JAROS E, PERRY RH, PERRY EK, WYPER D 2004 Nicotinic Acetylcholine Receptor Distribution in Alzheimer's Disease, Dementia with Lewy Bodies, Parkinson's Disease, and Vascular Dementia: In Vitro Binding Study Using 5-[125I]-A-85380. Neuropsychopharmacology 29: 108-116.

https://doi.org/10.1038/sj.npp.1300302

11. YAMADA M, MIYAKAWA T, DUTTAROY A, YAMANAKA A, MORIGUCHI T, MAKITA R, OGAWA M, CHOU CJ, XIA B, CRAWLEY JN, FELDER CC, DENG CX, WESS J 2001 Mice lacking the M3 muscarinic acetylcholine receptor are hypophagic and lean. Nature 410:207-12. https://doi.org/10.1038/35065604

12. GOTTI C, CLEMENTI F 2004 Neuronal nicotinic receptors: from structure to pathology. 74:363-396

13. EMDE A, EITAN C, LIOU L, LIBBY RT, RIVKIN N, MAGEN I, REICHENSTEIN I, OPPENHEIM, H, EILAM R, SILVESTRONI A, ALAJAJIAN B, BEN-DOV IZ, AEBISCHER J, SAVIDOR A, LEVIN Y, SONS R, HAMMOND SM, RAVITS JM, MOLLER T, HORNSTEIN, E 2015 Dysregulated miRNA biogenesis downstream of cellular stress and ALS-causing mutations: a new mechanism for ALS. EMBO J 34: 2633-51. https://doi.org/10.15252/embj.201490493

14. PHUKAN J, PENDER NP, HARDIMAN O 2007 Cognitive impairment in amyotrophic lateral sclerosis. Lancet Neurol 6:994-1003. https://doi.org/10.1016/S1474-4422(07)70265-X

15. GDYNIA HJ, KURT A, ENDRUHN S, LUDOLPH AC, SPERFELD AD 2006 Cardiomyopathy in motor neuron diseases. J Neurol Neurosurg Psychiatry77:671-3.

https://doi.org/10.1136/jnnp.2005.078600

16. MORITA H, YANAGISAWA N, NAKAJIMA T, SHIMIZU M, HIRABAYASHI H, OKUDERA H, NOHARA M, MIDORIKAWA Y, MIMURA S 1995 Sarin poisoning in Matsumoto, Japan. Lancet 346:290-3. https://doi.org/10.1016/S0140-6736(95)92170-2

17. RAUH VA, PERERA FP, HORTON MK, WHYATT RM, BANSAL R, HAO X, LIU J, BARR DB, SLOTKIN TA, PETER-
SON BS 2012 Brain anomalies in children exposed prenatally to a common organophosphate pesticide. Proc Natl Acad Sci U S A 109:7871-7876. https://doi.org/10.1073/pnas.1203396109

18. HUNTZINGER E, IZAURRALDE E 2011 Gene silencing by microRNAs: contributions of translational repression and mRNA decay. Nat. Rev. Genet. 12, 99-110. https://doi.org/10.1038/nrg2936

19. HATFIELD SD, SHCHERBATA HR, FISCHER KA, NAKAHARA K, CARTHEW RW, RUOHOLA-BAKER H 2005 Stem cell division is regulated by the microRNA pathway. Nature 435:9748. https://doi.org/10.1038/nature03816

20. GAO J, WANG WY, MAO YW, J GRÄFF J, GUAN JS, PAN L, MAK G, KIM D, SU SC, TSAI LH 2010 A novel pathway regulates memory and plasticity via SIRT1 and miR-134. Nature 466:1105-9.

21. GAO P, TCHERNYSHYOV I, CHANG TC, LEE YS, KITA K, OCHI T, ZELLER KI, DE MARZO AM, VAN EYK JE, MENDELL JT, DANG CV 2009 c-Myc suppression of miR-23a/b enhances mitochondrial glutaminase expression and glutamine metabolism. Nature 458:762-5. https://doi.org/10.1038/nature07823

22. GRIMSON A, FARH KK, JOHNSTON WK, GARRETTENGELE P, LIM LP, BARTEL DP 2007 MicroRNA Targeting Specificity in Mammals: Determinants Beyond Seed Pairing Mol Cell 27(1):91-105. https://doi.org/10.1016/j.molcel.2007.06.017

23. ZHANG J, LI S, LI L, LI M, GUO C, YAO J, MI S 2015 Exosome and Exosomal MicroRNA: Trafficking, Sorting, and Function. Genomics Proteomics Bioinformatics 13:17-24.

https://doi.org/10.1016/j.gpb.2015.02.001

24. GOLDIE BJ, DUN MD, LIN M, SMITH ND, VERRILLS NM, DAYAS CV, CAIRNS MJ 2014 Activity-associated miRNA are packaged in Map1b-enriched exosomes released from depolarized neurons. Nucleic Acids Res 42:9195-208.

https://doi.org/10.1093/nar/gku594

25. GUDURIC-FUCHS J, O'CONNOR A, CAMP B, O'NEILL CL, MEDINA RJ, SIMPSON DA 2012 Selective extracellular vesiclemediated export of an overlapping set of microRNAs from multiple cell types BMC Genomics 13: 357. https://doi.org/10.1186/1471-2164-13-357

26. SIMON DJ, MADISON JM, CONERYAL, THOMPSON-PEER KL, SOSKIS M, GARY B. RUVKUN GB, KAPLAN JM, KIM JK 2008 The microRNA miR-1 regulates a MEF-2 dependent retrograde signal at neuromuscular junctions. Cell 133: 903-915

27. SOKOL NS, AMBROS V 2005 Mesodermally expressed Drosophila microRNA-1 is regulated by Twist and is required in muscles during larval growth Genes Dev 19:2343-54.

https://doi.org/10.1101/gad.1356105

28. CHEN JF, MANDEL EM, THOMSON JM, WU Q, CALLIS TE, HAMMOND SM, CONLON FL, WANG DZ 2006 The role of microRNA-1 and microRNA-133 in skeletal muscle proliferation and differentiation. Nat Genet 38:228-33. https://doi.org/10.1038/ng1725

29. ZHANG H, FU Y, SU Y, SHI Z, ZHANG J 2015 Identification and expression of HDAC4 targeted by miR-1 and miR-133a during early development in Paralichthys olivaceus. Comp Biochem Physiol B Biochem Mol Biol 179:1-8. https://doi.org/10.1016/j.cbpb.2014.08.005

30. ZHANG H, FU Y, SU Y, SHI Z, ZHANG J microRNA-1 and microRNA-206 regulate skeletal muscle satellite cell proliferation and differentiation by repressing Pax7. Comp Biochem Physiol B Biochem Mol Biol 179:1-8. https://doi.org/10.1016/j.cbpb.2014.08.005

31. GOLJANEK-WHYSALL K, PAIS H, RATHJEN T, SWEETMAN D, DALMAY T, MÜNSTERBERG A 2012 Regulation of multiple target genes by miR-1 and miR-206 is pivotal for $\mathrm{C} 2 \mathrm{C} 12$ myoblast differentiation J Cell Sci 125:3590-600. https://doi.org/10.1242/jcs.101758

32. LIU N, WILLIAMS AH, MAXEINER JM, BEZPROZVANNAYA S, SHELTON JM, RICHARDSON JA, BASSEL-DUBY 
R, Olson EN 2012 microRNA-206 promotes skeletal muscle regeneration and delays progression of Duchenne muscular dystrophy in mice. J Clin Invest 122:2054-2065.

https://doi.org/10.1172/JCI62656

33. WILLIAMS AH, VALDEZ G, MORESI V, QI X, MCANALLY J, ELLIOTT JL, BASSEL-DUBY R, SANES JR, Olson EN 2009 MicroRNA-206 delays ALS progression and promotes regeneration of neuromuscular synapses in mice. Science 326:1549-1554. https://doi.org/10.1126/science.1181046

34. SHAKED I, MEERSON A, WOLF Y, AVNI R, GREENBERG D, GILBOA-GEFFEN A, SOREQ H 2009 MicroRNA-132 potentiates cholinergic anti-inflammatory signaling by targeting acetylcholinesterase. Immunity 31:965-73.

https://doi.org/10.1016/j.immuni.2009.09.019

35. SHALTIEL G, HANAN M, WOLF Y, BARBASH S, KOVALEV E, SHOHAM S, SOREQ H 2013 Hippocampal microRNA-132 mediates stress-inducible cognitive deficits through its acetylcholinesterase target. Brain Struct Funct 218:59-72.

https://doi.org/10.1007/s00429-011-0376-z

36. CATAPANO F, ZAHARIEVA I, SCOTO M, MARROSU E, MORGAN J, MUNTONI F, ZHOU H 2016 Altered Levels of MicroRNA-9, -206, and -132 in Spinal Muscular Atrophy and Their Response to Antisense Oligonucleotide Therapy. Mol Ther Nucleic Acids 5: e331. https://doi.org/10.1038/mtna.2016.47

37. CHEN JF, MURCHISON EP, TANG R, CALLIS TE, TATSUGUCHI M, DENG Z, ROJAS M, HAMMOND SM, Schneider MD, Selzman CH, Meissner G, Patterson C, Hannon GJ, Wang DZ 2008 Targeted deletion of Dicer in the heart leads to dilated cardiomyopathy and heart failure. Proc Natl Acad Sci U S A 105:2111-6. https://doi.org/10.1073/pnas.0710228105

38. IVEY KN, MUTH A, ARNOLD J, KING FW, YEH RF, FISH JE, HSIAO EC, SCHWARTZ RJ, CONKLIN BR, BERNSTEIN HS, SRIVASTAVA D 2008 MicroRNA Regulation of Cell Lineages in Mouse and Human Embryonic Stem Cells. Cell Stem Cell 2:219-29. https://doi.org/10.1016/j.stem.2008.01.016

39. YANG B, LIN H, XIAO J, LU Y, LUO X, LI B, ZHANG Y, XU C, BAI Y, WANG H, CHEN G, WANG Z 2007 The musclespecific microRNA miR-1 regulates cardiac arrhythmogenic potential by targeting GJA1 and KCNJ2. Nat Med 13:486-91. https://doi.org/10.1038/nm1569

40. AI J, ZHANG R, GAO X, NIU HF, WANG N, XU Y, LI Y, MA N, SUN LH, PAN ZW, LI WM, YANG BF 2012 Overexpression of microRNA-1 impairs cardiac contractile function by damaging sarcomere assembly. Cardiovasc Res 95:385-93. https://doi.org/10.1093/cvr/cvs196

41. ZHANG Y, SUN L, ZHANG Y, LIANG H, LIX, CAI R, WANG L, DU W, ZHANG R, LI J, WANG Z, MA N, WANG X, DU Z, YANG B, GAO X, SHAN H 2013 Overexpression of microRNA-1 Causes Atrioventricular Block in Rodents Int J Biol Sci 9:455-462

42. SHIFMAN JM, CHOI MH, MIHALAS S, MAYO SL, KENNEDY MB 2006 Ca2+/calmodulin-dependent protein kinase II (CaMKII) is activated by calmodulin with two bound calciums. Proc Natl Acad Sci U S A 103:13968-73.

https://doi.org/10.1073/pnas.0606433103

43. DECKER RS, DECKER ML, KULIKOVSKAYA I, NAKAMURA S, LEE DC, HARRIS K, KLOCKE FJ, WINEGRAD S 2005 Myosin-binding protein C phosphorylation, myofibril structure, and contractile function during low-flow ischemia. Circulation 111:90612. https://doi.org/10.1161/01.CIR.0000155609.95618.75

44. DING P, HUANG J, BATTIPROLU PK, HILL JA, KAMM KE, STULL JT 2010 Cardiac myosin light chain kinase is necessary for myosin regulatory light chain phosphorylation and cardiac performance in vivo. J Biol Chem 285:40819-29. https://doi.org/10.1074/jbc.M110.160499

45. BAGNALL RD, TSOUTSMAN T, SHEPHARD RE, RITCHIE W, SEMSARIAN C 2012 Global MicroRNA Profiling of the Mouse Ventricles during Development of Severe Hypertrophic Cardiomy- opathy and Heart Failure. PLoS One 7:e44744 https://doi.org/10.1371/journal.pone.0044744

46. ESKILDSEN TV, JEPPESEN PL, SCHNEIDER M, NOSSENT AY, SANDBERG MB, HANSEN PB, JENSEN CH, HANSEN ML, MARCUSSEN N, RASMUSSEN LM, BIE P, ANDERSEN DC, SHEIKH SP 2013 Angiotensin II Regulates microRNA-132/-212 in Hypertensive Rats and Humans. Int J Mol Sci 14:11190-207. https://doi.org/10.3390/ijms140611190

47. UCAR A, GUPTA SK, FIEDLER J, ERIKCI E, KARDASINSKI M, BATKAI S, DANGWAL S, KUMARSWAMY R, BANG C, HOLZMANN A, REMKE J, CAPRIO M, JENTZSCH C, ENGELHARDT S, GEISENDORF S, GLAS C, HOFMANN TG, NESSLING M, RICHTER K, SCHIFFER M, CARRIER L NAPP LC, BAUERSACHS J, CHOWDHURY K, THUM T 2012 The miRnA-212/132 family regulates both cardiac hypertrophy and cardiomyocyte autophagy. Nat Comun;3:1078.

https://doi.org/10.1038/ncomms2090

48. YANG Y, DEL RE DP, NAKANO N, SCIARRETTA S, ZHAI P, PARK J, SAYED D, SHIRAKABE A, MATSUSHIMA S, PARK Y, TIAN B, ABDELLATIF, SADOSHIMA J 2015 miR-206 Mediates YAP-Induced Cardiac Hypertrophy and Survival. Circ Res 117:891-904

49. NADORP B, SOREQ H 2014 Predicted overlapping microRNA regulators of acetylcholine packaging and degradation in neuroinflammation-related disorders Front Mol Neurosci 7:9. https://doi.org/10.3389/fnmol.2014.00009

50. SAILAJA BS, COHEN-CARMON D, ZIMMERMAN G, SOREQ H, MESHORER E 2012 Stress-induced epigenetic transcriptional memory of acetylcholinesterase by HDAC4. Proc Natl Acad Sci U S A 109: E3687-95. https://doi.org/10.1073/pnas.1209990110

51. COHEN TJ, WADDELL DS, BARRIENTOS T, LU Z, FENG G, COX GA, BODINE SC, YAO TP 2007 The Histone Deacetylase HDAC4 Connects Neural Activity to Muscle Transcriptional Reprogramming. J Biol Chem 282:33752-9. https://doi.org/10.1074/jbc.M706268200

52. BRUNETEAU G, SIMONET T, BAUCHÉ S, MANDJEE N, MALFATTI E, GIRARD E, TANGUY ML, BEHIN A, KHIAMI F, SARIALI E, HELL-REMY C, SALACHAS F, PRADAT PF, FOURNIER E, LACOMBLEZ L, KOENIG J, ROMERO NB, FONTAINE B, MEININGER V, SCHAEFFER L, HANTAÏ D 2013 Muscle histone deacetylase 4 upregulation in amyotrophic lateral sclerosis: potential role in reinnervation ability and disease progression. Brain 136:2359-68. https://doi.org/10.1093/brain/awt164

53. HUANG QK, QIAO HY, FU MH, LI G, LI WB, CHEN Z, WEI J, LIANG BS 2016 MiR-206 Attenuates Denervation-Induced Skeletal Muscle Atrophy in Rats Through Regulation of Satellite Cell Differentiation via TGF- $\beta 1$, Smad3, and HDAC4 Signaling. Med Sci Monit 22:1161-70. https://doi.org/10.12659/MSM.897909

54. FRIEDMAN A, KAUFER D, SHEMER J, HENDLER I, SOREQ H, TUR-KASPA I 1996 Pyridostigmine brain penetration under stress enhances neuronal excitability and induces early immediate transcriptional response. Nat Med 2(12):1382-1385. https://doi.org/10.1038/nm1296-1382

55. SAADEH AM, FARSAKH NA, AL-ALI MK 1997 Cardiac manifestations of acute carbamate and organophosphate poisoning. Heart 77: 461-464. https://doi.org/10.1136/hrt.77.5.461

56. JAYASINGHE SS 2012 Effects of acute organophosphate ingestion on cognitive function, assessed with the mini mental state examination. J Postgrad Med 58:171-5. https://doi.org/10.4103/0022-3859.101374

57. COLOVIĆ MB, KRSTIĆ DZ, LAZAREVIĆ-PAŠTI TD, BONDŽIĆ AM, VASIĆ VM 2013 Acetylcholinesterase Inhibitors: Pharmacology and Toxicology Curr Neuropharmacol11:315-35. https://doi.org/10.2174/1570159X11311030006 
58. OFEK K, HANIN G, GILBOA-GEFFEN A, BERSON A, GOLL Y, GREENBERG DS, SOREQ H, WILTON S 2011 Prophylactic Oligonucleotide-Mediated Enhancement of Host Acetylcholinesterase Protects from Organophosphate Poisoning. Defense Science Research Conference and Expo (DSR). https://doi.org/10.1109/DSR.2011.6026854

59. COLOVIĆ MB, KRSTIĆ DZ, LAZAREVIĆ-PAŠTI TD, BONDŽIĆ AM, VASIĆ VM 2013 Acetylcholinesterase inhibitors: pharmacology and toxicology. Curr Neuropharmacol 11:315-35. https://doi.org/10.2174/1570159X11311030006

60. ANAND S, SINGH S, NAHAR SAIKIA U, BHALLA A, PAUL SHARMA Y, SINGH D 2009 Cardiac abnormalities in acute organophosphate poisoning. Clin Toxicol 47:230-5. https://doi.org/10.1080/15563650902724813

61. MDAGHRI YA, MOSSADEQ A, FAROUDY M, SBIHI A 2010 Cardiac complications associated with organophosphate poisoning. Ann Cardiol Angeiol 59:114-7

62. KARKI P, ANSARI JA, BHANDARY S, KOIRALA S 2004 Cardiac and electrocardiographical manifestations of acute organophosphate poisoning. Singapore Med J 45:385-9

63. WANG J, CHEN J, SEN S 2015 MicroRNA as Biomarkers and Diagnostics. J CELL PHYSIOL 231: 25-30. https://doi.org/10.1002/jcp. 25056

64. TOIVONEN JM, MANZANO R, OLIVÁN S, ZARAGOZA P, GARCÍA-REDONDO A, OSTA R 2014 MicroRNA-206: A Potential Circulating Biomarker Candidate for Amyotrophic Lateral Sclerosis. PLoS One 9:e89065. https://doi.org/10.1371/journal.pone.0089065

65. DODGE JC, TRELEAVEN CM, FIDLER JA, TAMSETT TJ, BAO C, SEARLES M, TAKSIR TV, MISRA K, SIDMAN RL, CHENG SH, SHIHABUDDIN LS 2013 Metabolic signatures of amyotrophic lateral sclerosis reveal insights into disease pathogenesis. Proc Natl Acad Sci U S A. 2013 Jun 25;110:10812-7.

https://doi.org/10.1073/pnas.1308421110

66. NGO ST, STEYN FJ 2015 The interplay between metabolic homeostasis and neurodegeneration: insights into the neurometabolic nature of amyotrophic lateral sclerosis. Cell Regen (Lond). 2015 Aug 27;4:5. https://doi.org/10.1186/s13619-015-0019-6

67. DUPUIS L, PRADAT PF, LUDOLPH AC, LOEFFLER JP 2011 Energy metabolism in amyotrophic lateral sclerosis. Lancet Neurol 10:75-82. https://doi.org/10.1016/S1474-4422(10)70224-6

68. DESPORT JC, PREUX PM, MAGY L, BOIRIE Y, VALLAT JM, BEAUFRÈRE B, COURATIER P 2001 Factors correlated with hypermetabolism in patients with amyotrophic lateral sclerosis. Am J Clin Nutr 74:328-34

69. DESPORT JC, PREUX PM, TRUONG TC, VALLAT JM, SAUTEREAU D, COURATIER P 1995 Nutritional status is a prognostic factor for survival in ALS patients. Neurology 53:1059-63. https://doi.org/10.1212/WNL.53.5.1059

70. LIMOUSIN N, BLASCO H, CORCIA P, GORDON PH, DE TOFFOL B, ANDRES C, PRALINE J 2010 Malnutrition at the time of diagnosis is associated with a shorter disease duration in ALS. J Neurol Sci 297:36-9. https://doi.org/10.1016/j.jns.2010.06.028

71. KASARSKIS EJ, BERRYMAN S, VANDERLEEST JG, SCHNEIDER AR, MCCLAIN CJ 1996 Nutritional status of patients with amyotrophic lateral sclerosis: relation to the proximity of death. Am J Clin Nutr 63:130-7

72. PRADAT PF, BRUNETEAU G, GORDON PH, DUPUIS L, BONNEFONT-ROUSSELOT D, SIMON D, SALACHAS F, CORCIA P, FROCHOT V, LACORTE JM, JARDEL C, COUSSIEU C, LE FORESTIER N, LACOMBLEZ L, LOEFFLER JP, MEININGER V 2010 Impaired glucose tolerance in patients with amyotrophic lateral sclerosis. Amyotroph Lateral Scler 11:166-71. https://doi.org/10.3109/17482960902822960

73. VINOD M, PATANKAR JV, SACHDEV V, FRANK S, GRAIER WF, KRATKY D, KOSTNER GM 2016 MiR-206 is Expressed in Pancreatic Islets and Regulates Glucokinase Activity. Am J Physiol Endocrinol Metab 311: E175-85. https://doi.org/10.1152/ajpendo.00510.2015

74. HANIN G, SHENHAR-TSARFATY S, YAYON N, YAU YH, BENNETT ER, SKLAN EH, RAO DC, RANKINEN T, BOUCHARD C, GEIFMAN-SHOCHAT S, SHIFMAN S, GREENBERG DS, SOREQ H 2014 Competing targets of microRNA-608 affect anxiety and hypertension. Hum Mol Genet 23:456980. https://doi.org/10.1093/hmg/ddu170

75. KWON C, HAN Z, OLSON EN, SRIVASTAVA D $2005 \mathrm{Mi}-$ croRNA1 influences cardiac differentiation in Drosophila and regulates Notch signaling. Proc Natl Acad Sci U S A 102: 18986-18991. https://doi.org/10.1073/pnas.0509535102

76. HEIDERSBACH A, SAXBY C, CARVER-MOORE K, HUANG Y, ANG YS, DE JONG PJ, IVEY KN, SRIVASTAVA D 2013 microRNA-1 regulates sarcomere formation and suppresses smooth muscle gene expression in the mammalian heart. Elife 2: e01323. https://doi.org/10.7554/eLife.01323

77. SINGH A, HAPPEL C, MANNA SK, ACQUAAH-MENSAH G, CARRERERO J, KUMAR S, NASIPURI P, KRAUSZ KW, WAKABAYASHI N, DEWI R, BOROS LG, GONZALEZ FJ, GABRIELSON E, WONG KK, GIRNUN G, BISWAL S 2013 Transcription factor NRF2 regulates miR-1 and miR-206. J Clin Invest 123:2921-34. https://doi.org/10.1172/JCI66353

78. STRUM JC, JOHNSON JH, WARD J, XIE H, FEILD J, HESTER A, ALFORD A, WATERS KM 2009 MicroRNA 132 regulates nutritional stress-induced chemokine production through repression of SirT1. Mol Endocrinol 23:876-1884. https://doi.org/10.1210/me.2009-0117

79. KLÖTING N, BERTHOLD S, KOVACS P, SCHÖN MR, FASSHAUER M, RUSCHKE K, STUMVOLL M, BLÜHER M 2009 MicroRNA expression in human omental and subcutaneous adipose tissue. PLoS One 4: e4699.

https://doi.org/10.1371/journal.pone.0004699

80. Heneghan HM, Miller N, McAnena OJ, O'Brien T, Kerin MJ (2011) Differential miRNA expression in omental adipose tissue and in the circulation of obese patients identifies novel metabolic biomarkers. J. Clin. Endocrinol. Metab. 96, E846-E850. https://doi.org/10.1210/jc.2010-2701

81. ESTEP M, ARMISTEAD D, HOSSAIN N, ELARAINY H, GOODMAN Z, BARANOVA A, CHANDHOKE V, YOUNOSSI ZM 2010 Differential expression of miRNAs in the visceral adipose tissue of patients with non-alcoholic fatty liver disease. Aliment. Pharmacol. Ther. 32: 487-497. https://doi.org/10.1111/j.1365-2036.2010.04366.x 